Bol. Acad. peru. leng. 49. 2010 (41-84)

\title{
"EL INSPIRADO VATE HA SIDO DECLARADO EN REBELDÍA": RUBÉN DARÍO, JOSÉ SANTOS CHOCANO Y LA ESTAFA AL BANCO DE ESPAÑA
}

\author{
Günther Schmigalle \\ Badische Landesbibliothek Karlsruhe
}

\begin{abstract}
Resumen:
Desde muy joven José Santos Chocano luchó por conquistar el afecto de Rubén Darío, y éste le correspondió, aunque con su habitual timidez. La amistad de ambos alcanzó su mayor intensidad en 1905, en Madrid, donde los dos celebraron triunfos literarios; sufrió una crisis cuando Chocano se dejó involucrar en el famoso escándalo del Banco de España; y pasó después a otras etapas, entre ellas, la defensa de Darío por Chocano contra los ataques injustos de algunos compatriotas del nicaragüense; el intercambio de ideas sobre la Revolución mexicana que incidió fuertemente en la vida de ambos; y un último encuentro en Guatemala, ignorado hasta la fecha por los biógrafos darianos.
\end{abstract}

\section{Résumé:}

Dès qu'il est jeune Jose Santos Chocano a lutté pour gagner l'affection de Rubén Darío, et il lui a correspondu mais avec leur timidité habituelle. L'amitié entre les deux atteint son intensité maximale en 1905 à Madrid, où les deux ont fêté des triomphes littéraires ; elle a subi une crise lorsque Chocano s'est laissé impliquer au fameux scandale impliquant la Banque d'Espagne, et a passé ensuite à d'autres étapes, parmi elles, la défense de Dario par Chocano contre les attaques injustes des certains compatriotes du nicaraguayen, l'échange des idées sur la révolution mexicaine qui a 
influencé leurs vies, et une réunion finale au Guatemala, ignorée jusqu'à présent par les biographes darianos.

\begin{abstract}
:
Since he was very young, José Santos Chocano searched the affection of Rubén Darío and he repaid his generosity. Their friendship reached its intensity in Madrid, where both of them were celebrating their literary triumphs, but it became critical when Chocano was involved in the so called scandal of the Bank of Spain. This changed when Chocano defended Darío from the attacks of his Nicaraguan fellow men, the exchange of ideas on the Mexican Revolution which affected deeply their lives, and a final meeting in Guatemala, ignored so far by Dario 's biographers.
\end{abstract}

Palabras clave:

Darío, Rubén; Chocano, José Santos; amistad; biografía.

Mots clés:

Darío, Rubén; Chocano, José Santos, amitié, biographie.

Key words:

Darío, Rubén; Chocano, José Santos; friendship biography.

Fecha de recepción:

$14 / 01 / 2010$

Fecha de aceptación:

$19 / 01 / 2010$

En la amistad de Rubén Darío con el poeta peruano José Santos Chocano se siente desde el inicio una fuerte atracción mutua, pero también tensiones, frustraciones y (por parte de Dario) mucha reticencia. Chocano, que se consideraba descendiente de los incas y de los conquistadores y había estudiado matemáticas en un colegio alemán, tenía una fuerte necesidad por imponerse, por dominar, por luchar; también le gustaba manipular, cifrar, comparar y clasificar; amante de los guarismos, ponía fechas exactas a cada una de sus cartas, lo cual favorece a los investigadores de hoy. Darío admiraba sus exuberantes dones poéticos, pero se retraía al contacto con otros rasgos de su espíritu. Chocano, ocho años menor que Darío, luchó por conquistar y 
mantener la amistad del máximo poeta de América, con el cual se comparaba constantemente, y lo logró durante un tiempo. La relación de ambos llegó a una fuerte crisis en 1907/08, cuando Chocano se dejó involucrar en un sonado escándalo, el de la estafa del Banco de España.

\section{Los poetas se buscan y se rechazan}

En 1894, a la edad de 19 años, Chocano envía a Darío una carta, declarando su adhesión incondicional al movimiento modernista y ofreciendo unos versos para publicarse en la Revista de América. La carta -escrita en un tono entusiasta, combativo, casi exaltado- se encontraba todavía hace 50 años en el Seminario Archivo de Madrid, con una nota manuscrita de Darío (¿destinada a la posteridad?) explicando que no la contestó "por falta de tiempo". Hoy ha desaparecido, no se menciona en el catálogo de Villacastín (1987), ni está en el banco de datos actual, pero puede consultarse en el libro de Belmás (1960: 199-200), junto con muchas atinadas reflexiones.

Dos años después, en 1896, Chocano recibe en Lima un ejemplar de Los Raros, autografiado y enviado por Darío. Resentido, sin duda, por la falta de respuesta a su carta, Chocano, en un artículo publicado en la revista limeña La Neblina, critica el libro con vehemencia, reprochando a Darío el querer encerrar la nueva poesía americana "en el cartabón francés". Compara el libro de Darío con el de Gómez Carrillo, Literatura extranjera, afirmando la superioridad de Carrillo, y concluye: "Rubén Darío nos debe otra obra en que sea menos francés y más americano. Ensaye sus fuerzas, ensayémoslas todos". Recibe, sin embargo, con entusiasmo otro libro que Darío le manda, poco después: Prosas profanas. Y se va al valle de Chanchamayo, supuestamente para cultivar el café, pero en realidad para impregnar su mente y su poesía con paisajes americanos y tradiciones autóctonas, preparándose para su futuro papel como "cantor social, político, elegíaco, heroico y naturalista de la América" (GonzálezBlanco, 1908: XL; cf. Chocano, 1954: 1453-1456). 


\section{Los poetas se reúnen en Madrid}

En 1905, los dos poetas coinciden en Madrid, donde llegan con encargos similares: Chocano, desde Lima, viene como primer secretario de la misión peruana de límites con el Ecuador, presidida por el doctor Mariano H. Cornejo y destinada a solucionar la cuestión amazónica (Chocano, 1954: 1534); Darío, desde París, viene como miembro de la misión de límites con Honduras, presidida por Crisanto Medina, en ambos casos "siendo el rey Don Alfonso el árbitro que debía resolver definitivamente en el asunto en cuestión" (Darío, 1910: 261). Hacen amistad, Darío lleva al peruano a la confitería "La Mallorquina", a un restaurante de la Bombilla, y a una cervecería de la calle de Hileras, donde frecuenta una tertulia literaria, junto con Manuel Machado, Mariano de Cavia, Nilo Fabra y otros. Dice Chocano que "cuando Rubén era dueño de sí mismo ... mostrábase como un hombre grave, pero muy agradable, con innegable don de gentes, aunque parco de palabras y no muy ágil en sus actitudes" (Chocano, 1954: 1554). Al poco tiempo tienen tanta confianza que Darío llega a suplicar al amigo que le ayude en su lucha contra el demonio del alcohol y contra los malos amigos que lo incitan a beber. Chocano acepta, tratando de motivar al amigo para beber moderadamente, pero Darío se impone una abstinencia absoluta, que lo hace desmayar después de tres días. Los médicos llamados por Chocano le recetan una botella de coñac, y, ya ebrio, compone el famoso poema que comienza "Hay un tropel de potros sobre la pampa inmensa", donde llama a Chocano "amigo fiel", y que llega a figurar como preludio en el libro más famoso de éste, Alma América (Chocano, 1954: 1554-1556).

\section{Darío viaja}

A fines de junio de 1905 comienza a circular el nuevo libro de Darío, Cantos de vida y esperanza. En julio, Darío se traslada con Francisca Sánchez a San Esteban de Pravia (La Arena), para pasar el verano en la orilla del mar, en compañía de Ramón Pérez de Ayala y de los hermanos González-Blanco. Allí redacta las crónicas que después formaron la sección "En Asturias" de su libro Opiniones, y otras que hasta la fecha no se han incluido en ningún libro. Chocano, que se ha quedado en Madrid, le escribe el 5 de septiembre: 
Le decía a Ud. en mi tarjeta que si no cumplí con enviarle el libro de Lugones, fue porque Nilo Fabra lo tomó a su cargo y me aseguró que se lo enviaría en el acto: hoy ya sé que está en su poder. ¿Qué tal? Un libro de tanto talento como mal gusto. El saldo, en contra. ¡Es lástima! Tal mi opinión, siempre sincera.

A propósito, he leído el artículo de "La Nación" sobre Ud.; y lo califico de poco atinado, cualquiera que sea el aspecto en que se le considere. Yo alguna vez escribiré sobre Ud.; y, por lo mismo que camino por otro lado, creo que acertaré, en razón de que soy capaz de comprender lo comprensible y de sentir lo incomprensible.

Le diré a usted una agradable noticia: Nervo ha llegado. Viene como $2 .^{\circ}$ secretario de la legación mexicana; y aunque se ha vuelto a San Sebastián, estará aquí dentro de algunos días. Almorcé con él ayer, y me ha hecho muy simpática impresión: me habló de Ud. con cariño. En cambio, uno de sus devotos más fieles, me preguntó antier sobre si realmente se llamaba Ud. Rubén Darío. Yo me eché a reír como Ud. lo hará al saberlo. Hube de decirle que los americanos no nos cambiábamos de nombre. Esta gente, mi amigo, es la más insincera que yo conozco. ¿Será todo ello porque nosotros venimos de los Conquistadores y ellos de... los que se quedaron aquí? ¡Pobre España!

Me parece oportuno manifestarle a Ud. que he comprado su libro, porque Ud. se olvidó de dármelo. ¿Mi opinión? Ya Ud. la sabe. Aunque no hubiera en el libro más que la primera composición, sería bastante. Es la nota más sincera de su alma de Ud. ese primer canto. ${ }^{1}$

Se nota, en casi toda la carta, el tono arrogante y conflictivo del poeta peruano. El hoy "olvidadísimo poeta Nilo Fabra" (Doménech, 2003) era un ferviente admirador de Darío, quien lo menciona en su autobiografía calificandolo de "sutil poeta de sentimiento y de arte" (Darío, 1910: 219), y, en Opiniones, entre los "Nuevos poetas de España" incluye a "Nilo Fabra, que ha expresado sus quereres y soñares con modos refinados, dando a veces un tono menor que traduce sus prematuras

$1 \quad$ Ghiraldo, 1943: 232-233.

Bol. Acad. peru. leng. 49(49), 2010 
melancolías contagiosamente" (Darío, 1906: 227). Chocano le dedicó uno de los poemas de Alma América: "Pomme de Terre" (1954: 417). La obra de Lugones que no le gustó a Chocano fue sin duda Crepúsculos del Jardin (1905), "libro [que] se destaca entre los más bellos del Modernismo, a punto de haberse discutido con encarnizamiento la paternidad de su estilo entre los partidarios de Herrera y Reissig y los del argentino (ambos debieran haberse quedado con Albert Samain)" (Sánchez, 1960: 164-165). El artículo de La Nación sobre Darío es una crítica de Cantos de vida y esperanza, que llega a la conclusión de que "este nuevo joyel de versos que nos ofrece Darío, no guarda las preciosas alhajas de Prosas profanas. El orfebre se ha descuidado, o siente la fatiga, o no esculta sino a ratos perdidos y por entretenimiento. Salvo que quiera burlarse de los noveleros, y al hacerlo resulte esto: que ha suprimido las bellezas posibles, y ha exagerado los defectos, exagerando la originalidad ... A los que le imiten, Pegaso los hará rodar maltrechos. Esta es la razón que nos obliga a tanta franqueza". ${ }^{2}$ El libro de Darío que Chocano alaba es también Cantos de vida y esperanza. Refleja el carácter de Chocano el hecho de que junto con la alabanza viene un reproche: "he comprado su libro, porque Ud. se olvidó de dármelo". Y llama la atención que en el fondo alaba sólo uno -el primero- de los 54 poemas del libro, confirmando, sin querer, el juicio sobre "esos versos ora sonoros, ora torturados, ora elegantes, ora toscos y de una extravagancia voluntaria", que el crítico de La Nación compara con la prosa de Darío que "es hoy muy distinta y de mucho mayor valía filosófica y psicológica. Tiene, debajo, una armazón más sólida: tiene una armazón, y su libro de versos no la tiene. Creemos saber por qué: ya no escribe sus versos sino como desahogos; ya no es trovador; arraigado ya, trabajando, pensando, produciendo, canta por distracción a ratos perdidos, como el músico que deja correr las manos por las teclas con el pensamiento en otra parte". 3

Poco después, el 1. ${ }^{\circ}$ de diciembre de 1905, Darío está en París, y Chocano le escribe desde Madrid:

2 “'Cantos de vida y esperanza'. Versos y prosas”, La Nación, 4 de agosto de 1905, p. 4. Ibid. 
Agradezco mucho sus felicitaciones, porque sé de su cariño para mí y estoy seguro de la sinceridad que para mí tiene. Hubiérame gustado que hubiese Ud. presenciado mis "cosas" aquí, para que formara idea de mí tan exacta como la que de aquí tiene formada. "Esto", ya.

Me alegro mucho que haya acudido a mí para sus pequeños asuntos del baúl, etc. Le han ido, con toda precisión. El famoso Lázaro me ha ahorrado tiquis miquis con la policía: se ha portado satisfactoriamente. Supongo que en breve estará Ud. en posesión de sus cosas. Ya sabe, pues, que a mí debe acudir como a un buen hermano, como a su mejor hermano, para cualquier cosa que quiera en Madrid. ${ }^{4}$

Las felicitaciones de Darío que Chocano agradece se refieren sin duda a uno de los mayores triunfos que el poeta peruano pudo celebrar en Madrid: la velada en el Ateneo, el 19 de noviembre, durante la cual se conquistó la admiración del difícil público madrileño. ${ }^{5}$ La segunda parte de la cita indica que Darío recurrió a la ayuda de Chocano para la solución de algunos problemas relacionados con su traslado de Madrid a París. ¿Es cierto que Darío fue un inepto para las cosas de la vida práctica? Algunos autores así lo afirman, aunque el mismo Darío haya escrito, en una carta dirigida a Santiago Argüello, en 1909: "Es un general error, que conviene no contradecir mucho, el creer que yo ando por las nubes" (Darío, 2000: 294). De todos modos se nota que Chocano estaba muy contento de haber podido ayudarle. El personaje que menciona el poeta es sin duda un secretario de Darío, conocido como don Eduardo, de apellido Lázaro. ${ }^{6}$

El 27 de enero de 1906, Chocano, siempre desde Madrid, escribe a Darío, siempre en París:

4 Belmás, 1960: 201-202; SARD, documento n. ${ }^{\circ} 1455$.

5 Tenemos al respecto los testimonios de Antonio Palomero ("Notas al margen. A propósito de un poeta americano", ABC, 22 de noviembre de 1905, cit. en: Sánchez, 1960: 166), de Vargas Vila (carta a Darío, 20 de noviembre de 1905, en: Ghiraldo, 1943: 83) y de Nervo ("Una velada en honor de Navarro Ledesma. Un poeta americano", 1955: 1/1343-1344).

6 Belmás, 1960: 257-258; Belmás, 1968: 322; Torres, 1980: 540.

Bol. Acad. peru. leng. 49(49), 2010 
Supongo que habrá Ud. recibido las tarjetas postales que le he dirijido anteriormente. Mi libro estará dentro de pocos días concluido; é inmediatamente "marcharé sobre París".?

El libro al que se refiere Chocano es Alma América, que terminó de imprimirse el 22 de mayo de 1906; salió de las prensas con prólogos de Menéndez y Pelayo, Unamuno, y José Enrique Rodó, y con un preludio de Darío. No se sabe si Chocano cumplió con su promesa de "marchar sobre París"; ignoramos si alguna vez visitó el país de los galos, cuyo idioma ignoraba enfáticamente. En sus memorias, hablando de la impresión que le produjo la Avenida de Mayo en Buenos Aires, dice: "Sólo la Avenida de la Opera, en París, me ha dejado una impresión semejante" (Chocano, 1954: 1538), pero es difícil poner una fecha a este recuerdo.

A continuación, es el viaje de Darío a la Tercera Conferencia Panamericana en Río de Janeiro el que pone más distancia entre los dos amigos. Pocos días antes de la partida de Darío, el 22 de junio de 1906, Chocano le escribe:

¿Qué hay de su viaje á Río Janeyro? Dígame su opinión sobre mi libro. No se olvide de quien le quiere. Muchas gracias por sus hermosas "Opiniones".

Y después del regreso de Darío, el 8 de octubre de 1906:

Le felicito ante todo por haber llegado con salud completa á París; y le deseo el bienestar que se merece.

Tengo interés en saber si recibió Ud. ó no mi "Alma América"; porque, primeramente, se trata de un libro mío para Ud. y luego en él van sus cariñosos versos para mí. Si le es á Ud. fácil indíqueme la dirección de Ingegnieros y de Lugones; porque deseo enviarles mi libro. Le recomiendo á un muchacho compatriota mío -Francisco García Calderón (50 rue Jacob)-; es un mozo que vale de verdad. Si le llega á tratar algún día, hágalo con cariño; porque él lo merece: Ud. verá. ${ }^{9}$

7 Belmás, 1960: 202-203; SARD, documento n. 1456.

8 Belmás, 1960: 204; SARD, documento n. ${ }^{\circ} 1457$.

9 Belmás, 1960: 204; SARD, documento n. ${ }^{\circ} 1458$. 
No hay cartas que correspondan al año de 1907. En octubre de 1907, Darío viaja a Nicaragua; regresa a España en mayo de 1908 como embajador de su país, el cual ya había representado como cónsul en París.

\section{Retorno de Darío y nuevo encuentro en Madrid}

El lunes 18 de mayo de 1908, Darío llega a Madrid desde Nicaragua, vía Nueva York y París, para asumir su nuevo papel como embajador. ${ }^{10}$ Su viaje a Nicaragua le ha brindado una serie de triunfos y de fracasos. Triunfos, las recepciones, banquetes y conciertos con que el pueblo y los dignatarios lo agasajaron en León, Managua, Masaya y otros lugares. Triunfo, su nombramiento, el 21 de diciembre, como ministro residente de su país en la madre patria. Fracaso en sus proyectos más personales: aunque la ley de matrimonio fue modificada en su favor, su esposa legal, Rosario Murillo, pidió la suma inalcanzable de diez mil francos para acceder a la demanda de divorcio; suma que el terrible cuñado, Andrés Murillo, todavía aumentó a cincuenta mil. La soñada posición diplomática en España, también, se convierte pronto en pesadilla. Los sueldos que tendría que pagarle el gobierno de Zelaya llegan atrasados o no llegaban del todo; y don Crisanto Medina, su superior inmediato en la jerarquía diplomática y responsable para el pago de sus retribuciones, le hace la vida imposible con "su mezquindad, su malevolencia y su envidia" (Torres, 1982: 306).

Al llegar a Madrid, Darío se hospeda primero en una modesta casa de huéspedes de la calle del Río; después, por razones de decoro, se traslada al Hotel París, esquina a la Puerta del Sol y la calle de Alcalá. Ya el 21 de marzo, desde Madrid, José Santos Chocano había escrito a Francisca Sánchez, en París, preguntándole por la fecha de la llegada de Rubén y ofreciéndo sus servicios para buscar un piso adecuado para la Legación. Francisca Sánchez le contestó: "Doy a Vd. las gracias por sus finos ofrecimientos y créame que ya le avisaré lo que pensemos, por lo pronto, no tenemos prisa, pues he recibido cablegrama y carta de

$\overline{10}$ “Rubén Darío", El Liberal, 20 de mayo de 1908, p. 3.

Bol. Acad. peru. leng. 49(49), 2010 
D. Rubén avisándome que a causa de sus asuntos, permanecerá 16 días más en Centro América y no lo veremos sino hasta el próximo mes de mayo". ${ }^{11}$ Ahora en mayo, "en París continúan sus familiares, aguardando sus instrucciones. Por fin se vienen todos a la Fonda de Los Leones, desde donde acudirán a reunirse con el poeta en la casa número 27 ... de la calle Serrano" (Conde, 1964: 61), donde se instala la embajada. El martes 2 de junio, Darío presenta sus cartas credenciales al rey Alfonso XIII.

Un día antes, el $10^{\circ}$ de junio, Darío se reúne con Chocano. Éste le habla, seguramente, de su segundo libro publicado en España, Fiat Lux, que acaba de salir de las prensas el 22 de mayo, con un prólogo de Andrés González-Blanco celebrando la obra de Chocano como "fusión del lirismo y de la épica ... la más alta conquista de la humanidad culta y sensitiva" (1908: XLII). Darío, por su parte, manifiesta al amigo que se siente ofendido y preocupado por un artículo publicado en El Comercio, prestigioso diario de Managua, donde se critica el hecho de que, al partir de Nicaragua, había omitido despedirse "del grupo de distinguidas personas que le hicieron corte desde su llegada al país". ${ }^{12}$ El Comercio es uno de los periódicos nicaragüenses que, como cónsul en París, recibe de parte del Ministerio del Exterior de Nicaragua (Darío, 2000: 216). Vargas Vila ha descrito el contexto en el cual se produjo el ofensivo artículo: "En Managua, partido el poeta, se iniciaba una reacción contra su nombramiento, que había sido hecho bajo la presión de la admiración; sus enemigos se agitaban y sus amigos llegaban a temer seriamente un fracaso" (1972: 170-171). Chocano, siempre amistoso y servicial, a pesar de los grandes problemas que él mismo tiene en este momento, promete ayudar a Darío por medio de un artículo que escribirá en su defensa.

\footnotetext{
11 La fecha de esta carta de Chocano está mal transcrita, tanto en el libro de Carmen Conde (1964: 60), como en el banco de datos del SARD. La fecha correcta es 21 de marzo y no 21 de mayo de 1908.

12 J. B. Prado, "El regreso de Darío", El Comercio (Managua), 14 de abril de 1908.
} 


\section{Chocano huye de España y se tiene que defender}

Pero pocos días después, Darío recibe una carta de su amigo, escrita el 6 de junio de 1908 desde el puerto de Vigo, en el norte de España. El tono es más urgente y más íntimo, y se nota que los amigos han pasado del "usted" al "tú". La carta comienza así:

Mi querido Rubén:

Sea para tí mi única despedida. Imposible detenerme. No sé qué trágico presentimiento, aparte de las noticias, me lleva hacia mi padre, con fuerza mayor que todo. En el camino escribiré la carta a Managua; y desde La Habana la enviaré, proporcionándote un duplicado. Así también mi palabra aparecerá más desvinculada de tu influencia por la distancia. Ya sabes que te quiero de verdad; y que soy un hombre que sólo tiene el defecto de ser demasiado bueno.

A los que de mí te hablen mal, salúdalos muy cariñosamente por mi encargo: gusto devolver las lanzadas con sangre de mi espíritu, que se haga luz en los ojos de los que no me han podido ver bien. ${ }^{13}$

La partida precipitada de Chocano y su salida de España pudo ser motivada, en parte, por el presentimiento de la muerte de su padre, ${ }^{14}$ pero a la vez el poeta peruano tenía un motivo más inmediato y, si fuera posible, más dramático. El sábado, 26 de octubre de 1907, una persona desconocida cobró en el Banco de España la suma de 260.000 pesetas, contra la cuenta corriente de un señor Francisco Ansaldo, vizconde de San Enrique, ex diputado a Cortes, pariente del entonces Presidente del Senado y conocido capitalista. El estafador utilizó un talonario y una firma muy hábilmente falsificados. La estafa se descubrió el 30 de octubre, y unos días después fueron detenidos tres sospechosos: Vicente Pérez Cuesta y Juan Bautista Sanchiz (ambos empleados del Banco), y Francisco Villarias, "agente de negocios y propietario de una agencia de informaciones y

\footnotetext{
13 Belmás, 1960: 205-206; SARD, documento n. ${ }^{\circ} 1460$.

14 El padre de Chocano murió más de un año después, el 6 de septiembre de 1909, en Lima. Chocano no lo volvió a ver, ya que no había vuelto a su país: se había dedicado a visitar Cuba, República Dominicana, Estados Unidos, y Guatemala.
} 
confidencias en la calle de Ventura la Vega, número 8" ${ }^{15}$ Ahora bien, este último, "un hombre de unos cuarenta años, alto, bien vestido, con bigote negro", ${ }^{16}$ formaba parte del círculo de amigos que rodeaban a Chocano desde que, con el triunfo de su primer libro publicado en España, Alma América, se había convertido en un personaje conspicuo de la vida literaria y social española. Había entre ellos, a parte de poetas e intelectuales de alto nivel y de sinceros admiradores del arte, unos equívocos acólitos: "Como por su apostura recia y jactanciosa aparentase mayor bienestar del que poseía, no fue raro que algunos pillos se conchavasen para explotar la soberbia, la ambición y la manirrotez del artista" (Sánchez, 1960: 200). El hecho es que, pocos días antes de cometerse la estafa, Chocano se había dejado arrastrar para apoyar a Villarias en una actividad al margen de la ley. Y pocos días después de detenido Villarias, Chocano aparece en los diarios con declaraciones tratando de distanciarse del sospechoso amigo, pero enredándose en realidad más con él:

Como desde el día en que se descubrió esta estafa venía hablándose de la relación que con alguno de los detenidos pudiera tener cierto distinguidísimo poeta y diplomático americano, un redactor de "España Nueva" visitó ayer al Sr. Santos Chocano, que es la persona a quien el rumor aludía. He aquí las interesantes manifestaciones que hizo el distinguido literato:

"Yo conocía hace bastante tiempo a Francisco Merino Villarias. Digo Merino Villarias, porque así se llama, y no Montero Villarias, como he leído en todos los periódicos.

Fui presentado a él me parece que por un consocio suyo, llamado Isidoro Fernández. ${ }^{17}$

En mi último traslado de domicilio, de la Carrera de San Jerónimo, donde habitaba, convine en arrendarle a Merino las habitaciones

\footnotetext{
15 "La estafa al Banco de España”, El Imparcial, 5 de noviembre de 1907, p. 4.

16 "La estafa al Banco. Tres detenidos", La Correspondencia de España, 5 de noviembre de 1907, p. 3.

17 Isidoro Fernández fue consocio de Villarias en la Sociedad La Confidencia, disuelta, según parece, en febrero de 1907. Cf. "La estafa del Banco", ABC, 7 de noviembre de 1907, p. 7.
} 
que tuviera sobrantes en el domicilio ocupado por La Confidencia, de que él era director.

Desde hace unos meses ocupo estas habitaciones que usted ve, sin que para nada haya yo intervenido en los negocios de Villarias.

Sin embargo, sé que tenía entre manos el planeamiento de diversos negocios de importancia, uno en África y otro con un banquero inglés sobre suministros de la Deuda.

Recuerdo haber visto entrar con frecuencia en las oficinas a D. Vicente Pérez Cuesta.

Del otro señor detenido, D. Juan Bautista Sanchís, no puedo decir nada.

En lo que se refiere a mí, hasta la fecha no he sido llamado por el juez para que declare en los autos, aun cuando muy poco pudiera añadir a lo que ahora refiero.

En esta casa, repito, sólo figuro como un subarrendatario de las habitaciones sobrantes de esa Agencia de informaciónes, con la que no tengo la más insignificante relación.

El juzgado no ha venido todavía a incautarse de los papeles y documentos de Merino Villarias, que están tal como él los dejó el día que fue detenido." 18

Parece que el registro de los domicilios de los tres detenidos se realizó el 6 de noviembre, y el de las oficinas de la agencia de Villarias, el 8 , en presencia de Chocano ${ }^{19}$. Los periodistas vieron al poeta, esta noche, a las dos de la madrugada, en larga conversación con el comisario general de policía, Millán Astray, el padre del conocido general. ${ }^{20}$ El día

18 "La estafa de 265.000 pesetas", El Liberal, 7 de noviembre de 1907, p. 2.

19 "La estafa de 265.000 pesetas", El Liberal, 9 de noviembre de 1907, p. 9.

20 "La estafa del Banco", ABC, 7 de noviembre de 1907, p. 7; "La estafa al Banco", El Globo, 7 de noviembre de 1907, p. 2. Sánchez, al hablar del "famoso general Millán Astray, que era Comisario General de Policía de Madrid” (1960: 216-217), confunde al padre con el hijo. José Millán Astray (:1850?-1923), abogado, funcionario y escritor, autor de unas interesantes Memorias, fue comisario general de la policía y director de la cárcel Modelo de Madrid. José Millán Astray y Terreros (1879-1954) fue el fundador de la Legión Extranjera (Tercio de Extranjeros). Cf. Preston, 2006: 69-105. 
siguiente, ante el juez instructor, Chocano dio una declaración diferente de la que había brindado al periodista de España Nueva:

Ayer tarde ha declarado, ante el juez del Congreso, que instruye la causa, el poeta y diplomático Sr. Santos Chocano.

Su declaración ha sido muy larga.

Confirmó que Villarias rogóle permitiese que un notario extendiera un documento en el cual el (Villarias), se reconocía deudor de Chocano por una suma de 30.000 pesetas.

El Sr. Chocano no aceptó la proposición, diciendo a Villarias que, como tenía algunas deudas, no creía oportuno firmar tal documento.

Como Villarias insistió, manifestando que de no acceder a sus suplicas le causaría grave perjuicio, Chocano presentóle al novelista sudamericano D. Felipe Sassone, diciéndole que tal vez éste se allanaría a prestarle tal favor.

En efecto, el Sr. Sassone accedió a la petición de Villarias, y los tres fueron a una notaria, extendiendo el documento.

Este fue firmado también por Chocano, que lo autorizó como testigo.

En el acto de ser firmada la escritura, Villarias, para dar verosimilitud a su falsedad, y a fin de que el notario no sospechase nada, entregó al Sr. Sassone 3.000 pesetas en metálico.

Después de Chocano, compareció ante el juez el Sr. Sassone.

Confirmó lo dicho por aquél, y sostuvo que si se prestó al ardid de Villarias, fue por recomendación de su amigo. ${ }^{21}$

Este relato tiene varios aspectos curiosos; sería interesante poder conocer la declaración completa de Chocano. Queremos destacar sólo un aspecto: ¿por qué, al fin, accedió el poeta a la solicitud de su amigo y arrendatario, si no plenamente y en persona, por lo menos por la persona interpuesta de Sassone, y figurando él mismo como testigo? ¿Lo hizo por amistad? ¿Por generosidad? ¿Por ser demasiado bueno, como dice en la carta

21 "La estafa del Banco. Siguen las actuaciones", La Correspondencia de España, 9 de noviembre de 1907 , p. 3. 
a Darío? ¿Se dejó conmover por la afirmación de Villarias de que "de no acceder a sus suplicas le causaría grave perjuicio"? ¿O se dejó intimidar por ella? "De no acceder a mis suplicas usted me causaría grave perjuicio", en boca de un chantajista, puede significar: "... y en este caso yo me sentiría con derecho de perjudicarle gravemente a usted”. Villarias, como dijimos, fue propietario de la agencia La Confidencia y de la revista homónima, ambas especializadas en vender informes comerciales y quizás en difundir revelaciones picantes y escandalosas. Tal vez su negocio se parecía un poco al de Charles Augustus Milverton, personaje que Conan Doyle retrata en un cuento, en 1904. ¿Qué informaciones tenía Villarias sobre su amigo? ¿Sabía que el gobierno del Perú, después de financiar la publicación de Alma América, había aceptado, de manera muy seca, el 24 de abril de 1906, la renuncia del poeta como secretario de la legación especial peruana, de manera que, en 1907, contrariamente a lo que dicen los periódicos, ya no era "diplomático"? ¿Que el 3 de mayo del mismo año, el gobierno peruano, "por razones de decoro nacional", remitió 200 libras oro a su legación en España, "para solventar las deudas del ex secretario José Santos Chocano" (Sánchez, 1960: 204)? ¿Estaba al tanto de los romances del poeta, quien, todavía en 1906, de dos mujeres españolas, tuvo sendas hijas, la una llamada Angélica y la otra Esperanza (Sánchez, 1960: 173)?

Sea como fuere, con las declaraciones que hiciera Chocano al comisario de policía y al juez, "se desató la ira de Villarias, y lo que era amorfa sospecha se volvió acusación perentoria, o peligrosa calumnia ... Un amigo acude a avisar al poeta que Villarias prepara un terrible alegato contra él, y que la prisión es inevitable. Chocano emprende secreto viaje al Norte de España" (Sánchez, 1960: 214, 215). El 6 de junio de 1908, Chocano escribe la carta a Darío que citamos al inicio: "Sea para ti mi única despedida. Imposible detenerme", poniendo como pretexto a tal imposibilidad, un "trágico presentimiento" respecto a la salud de su padre. El 8 de junio leemos en un diario de Madrid:

Bilbao 7 (3-55 t.). Santos Chocano, llamado urgentemente por un telegrama de Lima, ha embarcado hoy en este puerto para el Perú, sin despedirse de nadie. 
Ha dejado como despedida una composición notable, que publicará EL LIBERAL.

Ha prometido enviar una salutación a España al llegar al Perú.

EL LIBERAL en Bilbao. ${ }^{22}$

El 4 de septiembre, los periódicos madrileños informan que "la causa instruida por estafa de 250.000 pesetas al Banco de España volverá al juzgado para la práctica de nuevas diligencias sumarias y para que se dicte auto de procesamiento contra el poeta Santos Chocano, como solicitó en tiempo el abogado de aquella entidad de crédito, Sr. Zapata. La Audiencia ha revocado el auto que dictó la autoridad inferior en 17 de Junio último, y manda que se comunique la resolución al juez del distrito del Congreso para que proceda al procesamiento de Santos Chocano por existir en el sumario indicios suficientes de su participación en el delito de falsedad y estafa que se persigue. Santos Chocano reside actualmente en la Habana, donde se le acaba de tributar un homenaje" 23 y de donde envía la "composición notable" anunciada en El Liberal: un poema en prosa titulado "Las Velas españolas (Á propósito de la 'Nautilus')". ${ }^{24}$

El miércoles, 13 de octubre de 1909 comienza la vista del proceso por la estafa del Banco. Aparecen, como procesados, Villarias, Pérez Cuesta y Sanchiz, pero los periódicos mencionan a Chocano como "presunto culpable", ${ }^{25}$ explicando que "se encuentra lejos de España", 26 o especificando que "huyó a América apenas recayó contra él el auto de procesamiento", 27 que "se halla en rebeldía" 28 "hállase declarado rebelde", 29 "continúa en rebeldía", ${ }^{30}$ o, de una forma más irónica: "El

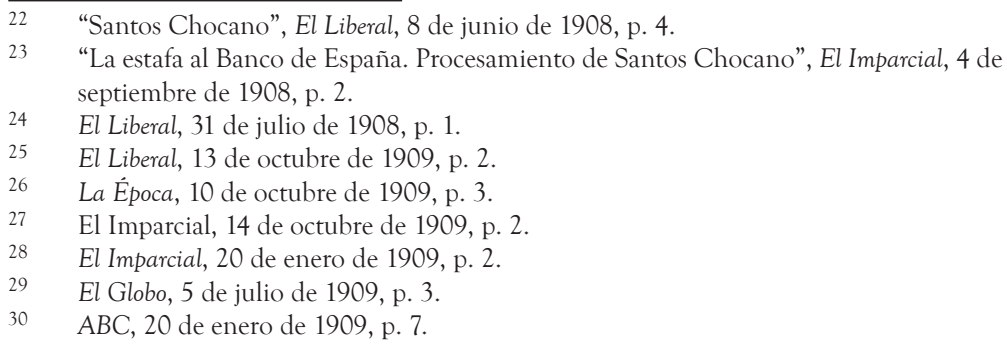


inspirado vate ... ha sido declarado en rebeldía" ${ }^{31}$ En el proceso declaran como testigos el amigo de Chocano, Felipe Sassone, y su abogado, Alfonso Azcárraga; pero son interrogados, por supuesto, no sobre Chocano sino sobre Villarias. También declara el renombrado banquero don Enrique García Calamarte y se comprueba que "banqueros tan conocidos como los señores Urquijo, García Calamarte, Banco Hispano-Americano y Crédit Lyonnais, utilizaban los servicios de informes comerciales que facilitaba La Confidencia". ${ }^{32}$ El 19 de octubre, Villarias, encontrado culpable por el jurado, es condenado a la pena de ocho años y un día de presidio mayor, accesorias, costas e indemnización al Banco de 350 mil pesetas. Curiosamente, los empleados del Banco, Pérez Cuesta y Sanchiz, son absueltos. ${ }^{33}$ Chocano, como sabemos, se encontraba ya lejos; nunca se pidió su extradición. Sobre los daños que el escándalo hizo a su reputación como persona y como poeta, citaremos las reflexiones de un escritor contemporáneo. El título de este artículo alude al conocido refrán, "Del árbol caído todos hacen leña", pero también al poema "Árbol caído" del libro Fiat lux, publicado por Chocano, como dijimos, en mayo de 1908:

La crónica es una agravante moderna de los males que afligen a los hombres. A un señor se le escapa la mujer con otro, o bien le procesan, o le dan un timo, o lo asesinan. Como no tenga la suerte de que en aquella ocasión haya plétora de asuntos... crónica al canto. Saldrá algún profesional del ingenio, o saldrán varios, a buscar el aspecto cómico de aquellos sucesos, para entretener al respetable público a costa de la víctima. Así como se dice: ‘Dichosos los pueblos que no tienen historia!', podría decirse: ‘Dichosas las personas que no dan asuntos a la crónica!'

No ha tenido esta fortuna el poeta peruano don José Santos Chocano, que vivió algún tiempo en Madrid y publicó aquí un par de libros. El Sr. Santos Chocano ha sido procesado como coautor

\footnotetext{
31 El Globo, 15 de octubre de 1909, p. 3. La cursiva está en el texto.

32 El Imparcial, 16 de octubre de 1909, p. 2.

33 El Globo, 20 de octubre de 1909, p. 2.
} 
o cómplice de la estafa de Villuendas al Banco. Como si no fuera bastante un contratiempo tan poco poético, los cronistas la han emprendido con él, y le maltratan, no a título de estafador, sino de poeta. Un cronista de El Mundo dijo que el juez debía haber tenido el valor de sus convicciones, y haber procesado a Chocano por mal poeta. Bonafoux añade que el titulado vate Chocano, como tal vate, merecía haber muerto en garrote vil. Cualquiera diría que estos cronistas estaban subvencionados por las Musas para apartar de la cofradía de los poetas el descrédito del auto de procesamiento que pesa sobre Chocano, al modo que acuden a veces a los periódicos personas timoratas con rectificaciones del tenor siguiente: 'El conocido comerciante D. Pedro Fernández nos ruega que hagamos constar que el Manuel Jiménez detenido ayer en la Plaza de Antón Martín hace mucho tiempo que no forma parte de la dependencia del acreditado establecimiento del Sr. Fernández'.

Discrepo de estos cronistas. Profeso en la materia ideas tan retrógradas y materialistas, que la más insignificante estafa me parece mucho más grave que el mayor de los crímenes literarios. Hay que considerar, además, que los crímenes contra la poesía son inofensivos. Por hacer malos versos no se debe procesar a nadie, ni mucho menos condenarle a garrote vil. Ni siquiera retirarle el saludo. En un país donde no se leen los versos, ¿qué daño le hace a nadie que haya un señor que los escriba malos? Que haya un coplero más, ¿qué le importa al mundo? Un par de botas mal hechas, o un entrecôte pasado, son mucho más perniciosos para la Humanidad que un soneto defectuoso, una oda coja o un madrigal empachoso y tonto.

Pero, además, ¿Chocano ha escrito tan malos versos como dicen desde que está procesado por estafa? Si yo fuese un espíritu tímido, no me atrevería a decir que no, puesto que Bonafoux asegura que dicho poeta pertenece al número de los genios americanos que alcanzan bombos en Madrid convidando a los periodistas a un biftec con patatas, ofreciéndoles cinco duros o amenazándoles con un desafío. No conozco lo bastante las costumbres literarias de 
mis contemporáneos, ni apenas me trato con literatos, para poder emitir opinión acerca de la tesis de Bonafoux. En el caso particular de Chocano, no creo en lo de los biftecs, los cinco duros, ni los desafíos. Un sujeto que se junta con perdularios como los que figuran en el proceso que ha dado a Chocano esta desagradable celebridad, por lo regular no está en situación de convidar a nadie, sino de que lo conviden a él. Tampoco ha llegado a mis oídos que Chocano fuese un hombre terrible, capaz de arrancar bombos por intimidación. Probablemente el único a quien ha dado un susto en Madrid es al Banco de España, si resulta verdad lo de la estafa.

No: Chocano podrá ser un buen estafador, pero no es un mal poeta, por desagradable que esto resulte para las Musas en las actuales circunstancias. Mírense en su espejo los poetas, y guárdense de cometer ninguna estafa; pues no sólo perderán la fama de personas decentes, sino también la de buenos versificadores.

Esta podría ser la moraleja del caso de Chocano (una moraleja suficientemente moral); pero yo quiero añadir otra más piadosa, aunque sea vulgar y sencilla. Es un dolor ver a un hombre de talento que, bien o mal, ha tenido comercio con la divina Poesía, mezclado en estos sucios asuntos. ¡Es una caída que debe inspirar lástima, más que burlas! ${ }^{34}$

Pero Chocano todavía no se siente como árbol caído, ni quiere inspirar lástima. Emprende varias acciones para defenderse, para limpiar su honor, y para reconquistar los favores del público en España.

En septiembre, publica en un importante diario cubano una declaración tratando de distanciarse tanto del Banco de España como del señor Villarias:

34 Andrenio, "Diario de un Espectador. - Del árbol caído...", La Época, 30 de septiembre de 1908, p. 1. Andrenio es el seudónimo del escritor y periodista Eduardo Gómez de Baquero (1866-1929).

Bol. Acad. peru. leng. 49(49), 2010 
Yo, por suerte, nunca cobré check en tal Banco, ni tuve cuentas corrientes en él, ni traté a sus empleados, ni tuve que hacer nada con esa entidad. Todos los indicios contra mí descansan en el hecho de que uno de los acusados tenía sus oficinas en la casa en que yo vivía, lo que es costumbre vulgarísima en Madrid: mis relaciones con el Director de Confidencia están esclarecidas en el informe reservado que poco tiempo antes de la estafa, prestó a una institución bancaria desfavorable a la solicitud que yo había hecho entonces de un crédito personal. Esto obra en autos; y no creo que se pueda exigir mayor desvinculación entre el que vive en una casa y el que tiene sus oficinas en ella. ${ }^{35}$

Podemos creer que Chocano no haya tenido relación alguna con el Banco de España; pero sus declaraciones con respecto a Villarias no convencen. Si ahora declara que "uno de los acusados tenía sus oficinas en la casa en que yo vivía", en sus declaraciones en noviembre de 1907 había dejado claro que no sólo era vecino, sino subarrendatario de Villarias: es una relación más estrecha. Si ahora afirma que sus relaciones con Villarias "están esclarecidas en el informe reservado que poco tiempo antes de la estafa, prestó a una institución bancaria desfavorable a la solicitud que yo había hecho entonces de un crédito personal", esto puede ser una parte de la verdad: pero en noviembre de 1907 había dejado claro que antes (¿o después?) le había ayudado a escamotear unos 30.000 pesetas.

A continuación, Chocano afirma que

la poca luz que el Banco de España puede aprovechar en este proceso ha sido proporcionada por mis declaraciones ... El Comisario General de Policía de Madrid sabe cuál fue siempre mi actitud en este asunto. Por eso, estoy seguro de que la atmósfera pública me ha de acompañar con sus simpatías en Madrid... ${ }^{36}$

35 “Una carta del Sr. José Santos Chocano", Diario de la Marina (Habana), 22 de septiembre de 1908, en: Chocano, 1954: 971-972. Ibíd. 
Para reconquistar las simpatías de la "atmósfera pública", Chocano aprovecha, ya antes de publicar la carta que acabamos de citar, la visita a Cuba de la corbeta Nautilus. Ésta, un buque escuela de la Armada española que había dado la vuelta al mundo en los años 1892-1894, visitó, el 24 de junio de 1908, el puerto y la ciudad de La Habana, donde fue recibida con muestras de cariño. "Las fiestas a los marinos del 'Nautilus' fueron abrumadoras" (Sánchez, 1960: 238). Chocano redacta, con ese motivo, un poema en prosa lleno de entusiasmo, que se publica en La Habana y en Madrid y donde la Nautilus se convierte en símbolo de los más altos valores de la Hispanidad. El texto termina así:

Allá va la nave... Esta es la nave de Colón, de Cortés y de Magallanes; esta es la nave de la Raza. Allá va la nave... digamos señalando el inescrutable Porvenir; y reflexionemos luego, como el gran romántico, con los brazos cruzados filosóficamente:

- ¡Quién sabe do va!.... ${ }^{37}$

El final del poema, con su referencia al "inescrutable Porvenir" y a las incertidumbres que implica la vida de las razas, de los pueblos y de los individuos, revela que el poema es también un reflejo de la situación personal del poeta. "Es evidente que tan amargos sucesos han madurado -y hasta ablandado- al poeta por dentro. ... No puede negar ya que sufre, y que sufre no para destilar rimas, sino que rima porque sufre" (Sánchez, 1960: 248). Si en la citada carta a Darío invita al amigo, "Á los que de mí te hablen mal, salúdalos muy cariñosamente por mi encargo: gusto devolver las lanzadas con sangre de mi espíritu, que se haga luz en los ojos de los que no me han podido ver bien", en su poema "Serenamente", escrito en La Habana en 1908, dice:

Cuantos me han calumniado

y me han escarnecido

dieron tal magnitud a mi pecado

que me duele el no haberlo cometido.

37 “Las velas españolas (A propósito de la «Nautilus»)", Diario de la Marina (Habana), 25 de junio de 1908; El Liberal (Madrid), 31 de julio de 1908, p. 1; Chocano, 1954: 975 976. La cita es de Espronceda. 
Si grande es la aventura

bendigo yo la trama

en que se urde el afán de la impostura

que sólo es el reverso de la fama. ${ }^{38}$

\section{Chocano defiende a Darío}

Por fin, hay que mencionar que Chocano cumplió con lo que había prometido a Darío: defenderlo contra los ataques de un compatriota. La frase que citamos, en su carta del 6 de junio, "En el camino escribiré la carta a Managua; y desde La Habana la enviaré, proporcionándote un duplicado”, se refiere al artículo que prometió escribir, y escribe, en defensa del amigo. Citemos primero el artículo en el cual se había atacado a Darío:

Algunos diarios de la prensa nacional han hablado en términos poco satisfactorios con ocasión del viaje de Darío, quien durante varios meses fue huésped de Nicaragua, después de una larga ausencia de la tierra natal.

Francamente, las exquisitas manifestaciones de admiración y simpatía, las elevadas muestras de cariño que recibió no sólo del país entero, sino del elemento oficial, el homenaje que la prensa toda tributó al eximio poeta, no se compadecen con su manera extraña de partir. Se sabía que el poeta, un tanto mal de salud, pasaba una temporada en la isla del Cardón, en compañía del doctor Debayle que durante su permanencia le prodigó los más sinceros agasajos, consagrándose por completo a hacerle lo más grato posible su estada en Nicaragua. En la isla estuvo cerca de un mes, volvió a Managua a despedirse del presidente de la República, según se dijo, y olvidándose del grupo de distinguidas personas que le hicieron corte desde su llegada al país, se fue a Corinto, tomó un vapor de la Pacific Mail e hizo rumbo a Panamá. Su partida se supo cuando los diarios publicaron el rol de pasajeros. Como se

$38 \quad$ Chocano, 1954: 637. 
comprenderá no poca sorpresa causó aquel viaje inesperado.

Quien había sido objeto de tantas atenciones en su patria, quien hizo su entrada a Nicaragua, entre inmensas y entusiastas aclamciones de todo un pueblo que anhelante esperó el arribo del poeta, quien venía hollando flores desde su trayectoria de Corinto a Managua, no ha debido por natural cortesía, ausentarse de su país de manera tan extraña e inusitada.

Queremos recordar la noche que Darío llegó a Managua.

Una ovación que traspasó los límites de lo ordinario, una tempestad de júbilo y aclamaciones, vibró en torno de él.

Fue aquello una entrada triunfal como pocas veces se han visto en Managua. Profusión de coronas simbólicas que las sociedades y escuelas nacionales le ofrecían a su paso, manos anhelantes que querían estrechar las suyas, ojos femeninos que con ansia deseaban ver de nuevo al prestigiado cantor que tanta luz ha derramado sobre la tierra maternal, el pueblo entero congregado en nuestras calles y parque central, aclamándolo entre los esplendores de aquella regia recepción; luego su entrada al Gran Hotel, donde innúmeras comisiones le esperaban para darle el saludo de bienvenida.

Una noche en León -doña Fidelina de Castro- dama culta y amable, la Recamier occidental, como la llamó Emiliano Hernández, ornó su casa con las más finas rosas de la tierra y en una decoración griega simbolizó en volcanes de flores los volcanes de la Patria.

La casa de la estimable señora fue esa noche un palacio: se esperaba a Rubén Darío para departir y cenar con él en la alegría de la Noche Buena, entre búcaros de bellezas metropolitanas. Y Darío, tan informal como ilustre, no asistió. Se dijo que estaba enfermo, y a la verdad no se mentía. Afortunadamente, en las leyes de la cortesía el bochorno no es para el que obsequia sino para el obsequiado, si éste falta a la cultura. 
Comentarios duros, reminiscencias de hechos lejanos, observaciones rudas y ardientes ha provocado la manera cómo se fue el poeta, y ello nos da ocasión para saber una vez más hasta dónde quieren los genios llevar su inmunidad, y cómo entienden ellos las prácticas de la cortesía.

La galantería oficial quiso dispensar también su homenaje al poeta; y el general Zelaya le nombró ministro de Nicaragua residente en España, puesto que habrá de desempeñar en la Coronada Villa, y que ha de llevarle grandes honores y no pocas altas consideraciones.

Ante las cosas a que nos hemos referido, no encontramos una justificación indulgente, ni explicación que satisfaga. Debemos convencernos con triste convencimiento que todos estos hechos sólo reconocen por causa la indeferencia que a Darío le merece Nicaragua, la escasa y quizá la ninguna consideración que lleva para sus amigos y admiradores, y la importancia negativa en que tuvo para cuantos homenajes se le hicieron.

¿Pudiera decirse por esto que Rubén Darío es un ingrato?

Quién sabe. Vale más pasar por alto el calificativo que tales hechos merecen, y concretarse tan sólo a referirlos para que cada cual, con criterio propio, lo juzgue a su antojo.

Vale también recordar la noche de la gran velada que dio en su honor el elemento intelectual de la metrópoli. Su discurso resultó una pieza incoherente y de una factura que desdice de los prestigios de su gran talento y su encantadora manera de decir.

Se había hablado, y él mismo lo decía, que su discurso iba a ser una obra fundamental, un plato de resistencia, lleno de sabias enseñanzas que dejaría a la juventud de Nicaragua; y bien sabemos lo que fue; el fracaso más absoluto. 
Sin embargo, el público lo escuchó, decimos mal, no lo escuchó, porque su discurso no podía oírse, le vió en el escenario con asiduo respeto, hasta que terminó.

El más terrible desencanto circuló entre todos, y a pesar de ello, la benevolencia siguió siendo la misma para él, y las ovaciones no se interrumpieron, siguieron tributándosele en medio de los acerbos comentarios que empezaban a desatarse.

Lección para el porvenir, ejemplo que nos dice de cuanto es capaz la vanidad de un poeta, y hasta donde puede llegar Rubén Darío, para quien no tuvo Nicaragua, sino las flores más hermosas de sus campos, y la más acabada cortesía, como homenaje para el altísimo poeta, orgullo de un continente, y maestro de la juventud intelectual de la América Hispana. ${ }^{39}$

Chocano envía su artículo-respuesta al diario El Comercio de Managua que, aparentemente, lo publica. También se publica en el Diario de la Marina de La Habana, de donde lo tomó Sánchez para su edición de Obras completas. Dice, entre otras cosas:

En tanto que la prensa española se colmaba de noticias alarmantes de todas las repúblicas de América -crisis política en la Argentina, crisis económica en México, revolución en el Perú, atentado en Guatemaladeslizóse por entre ellas el eco simpático de la acogida que Nicaragua había dispensado a su poeta. Los hispanoamericanos residentes en Madrid tuvieron ese solo instante de satisfacción y de orgullo.

No es patriótico, pues, aminorar un solo punto ese éxito, gallardamente alcanzado para América por el pueblo de Nicaragua, cuyos entusiasmos ha sabido interpretar el Presidente Zelaya, al honrar a R. D. con la más alta investidura diplomática. ${ }^{40}$

\footnotetext{
39 J. B. Prado, "El regreso de Darío", El Comercio (Managua), 14 de abril de 1908.

40 "Rubén Darío, diplomático", Diario de la Marina (Habana), 30 de junio de 1908; Chocano, 1954: 977-978.
} 
Y:

Enorgullézcome de cumplir al decirlo con un alto deber, no de compañerismo literario, sino de patriotismo continental: creo ser en este punto insospechable. Téngome por poeta de América que nada representa dentro del tutelaje del gran R. D. Nada es más distinto de la gracia de su arte que la fuerza del mío. Y, sin embargo, o acaso por lo mismo, nadie le aprecia más como poeta grande y como hombre bueno. Sé de sus debilidades geniales, pero también sé de sus cualidades únicas... ${ }^{41}$

En cuanto a los reproches concretos formulados por J. B. Prado, Chocano responde:

Y luego sorprenden los dos cargos que envuelve en su querella: censura a R. D. el que por una enfermedad no hubiese acudido a la fiesta de una gran dama y el que hubiese preferido salir discretamente de su país a anunciar su marcha como en solicitud de nuevas aclamaciones... Sin conocer a esa gran dama, cuyo talento ya me es simpático por la fiesta que organizara, estoy seguro de que habrá lamentado, pero no censurado la ausencia del poeta, cuyo disgusto por ello tuviera que ser grande; y conociendo como conozco a los elementos dirigentes del pueblo de Nicaragua, estoy también seguro de que sabrán apreciar cómo el carácter de diplomático vedaba al poeta, aun suponiendo que lo anhelase, presentarse en requerimiento de sonoras despedidas y aclamaciones desbordadas. ${ }^{42}$

Sabemos hoy que Fidelina Santiago de Castro (1871-i?) fue amiga de infancia de Rubén Darío, que se casó con Francisco Castro, íntimo amigo del poeta, y que tuvo un papel prominente "en los festejos del recibimiento apoteósico de Darío en 1907. Ella acompañó a Darío, junto con doña Casimira Debayle, en el carruaje que Rubén abordó al llegar a la estación de tren en León. En la sucesión de banquetes y festejos, no

$41 \quad$ Ibid. 
podía faltar la fiesta en honor de Darío organizada por Francisco Castro, entonces Ministro de Hacienda del Presidente Zelaya y su esposa Fidelina. Rubén no pudo asistir por encontrarse indispuesto". Y efectivamente, ni Fidelina ni su esposo se disgustaron con Darío por ello, ya que "en la Semana Santa de marzo de 1908 coincidieron en la Isla del Cardón, frente a Corinto", y al despedirse de Nicaragua, escribió el poeta en el abanico de doña Fidelina un célebre madrigal (Tünnermann Bernheim, 2009: 224, 221). De todos modos, el artículo de Chocano es bello y hábilmente redactado, y Darío podía sentirse satisfecho de la manera como lo defendía su amigo.

\section{Darío se olvida de Chocano}

El artículo es bello, hábil, y evidentemente sincero; pero con todo tenemos que hacer la pregunta: ¿lo redactó Chocano con algún pensamiento estratégico? ¿O por lo menos esperaba reciprocidad? ¿Pensaba que, si él defendía a Darío en su patria, Darío iba a defenderlo a él ante el público de España? Su biógrafo, severo como siempre, afirma: "La noticia a Darío no tiene otro objeto que usar a éste como portavoz de sus andanzas ante los medios intelectuales de España ...: no lo consiguió" (1960: 217). Efectivamente, lejos de asumir la defensa de Chocano, Darío ni siquiera le agradece el artículo que éste ha publicado en su defensa. En una tarjeta escrita el $1 .^{\circ}$ de diciembre de 1908 en Nueva Orleáns, Chocano reclama al amigo:

¿No recibiste el artículo que me pediste? ¿No lo viste reproducido en "El Comercio" de Managua?

Las circunstancias fuertes hacen las fuertes amistades. Extraño es tu silencio. ${ }^{43}$

Las "circunstancias fuertes" se refieren sin duda a la polémica que, para esa fecha, había estallado en América acerca de la persona de Chocano. El poeta, tratando de justificarse en un soneto, "La gloria del

43 Belmás, 1960: 207; SARD, documento n. ${ }^{\circ} 1461$.

Bol. Acad. peru. leng. 49(49), 2010 
proceso", escrito en Nueva Orleans en septiembre de 1908 (1954: 657658), fue atacado por el poeta mexicano Juan de Dios Peza en tres sonetos terribles e injuriosos que se titulan "Chocano en Cuba", "Chocano en Guatemala" y "Chocano huye", publicados en México y en Costa Rica. Rafael Heliodoro Valle criticó su amistad con el presidente guatamalteco Estrada Cabrera en una serie de siete artículos titulados "Estrada Cabrera juzgado por José Santos Chocano", publicados en el Diario del Hogar de México en agosto de 1908; Chocano se defendió en un artículo publicado en el Diario de la Marina de La Habana, el 20 de agosto de 1908 (1954: 987-989). En otros poemas fue atacado anónimamente (Romero de Valle, 1963: 236-237). El 11 de diciembre de 1908, Chocano escribe a Darío, desde Nueva York:

Mi querido Rubén:

Acabo de leer la carta en que le hablas a Fiallo de mí y tu soneto A un poeta que sin duda es para mí. Veo que no me has olvidado: haces bien. Tengo un alma que merece toda la admiración y el cariño de quien sea capaz de sentir y pensar superiormente. Mi tarjeta de Nueva Orleans te habrá hecho entender que al extrañar tu silencio dábate la admiración, el cariño que te mereces.

Mis asuntos -todos trascendentales- tienden a componerse ¡Oh voluntad! Lástima de siglo XV, que no tuvo el honor de saber de mí... Acabo de recibir una carta del abogado del Banco de España, con quien he conseguido cartearme, que me abre una perspectiva de solución. ¡Ya verán los menguados! ${ }^{44}$

En esta carta encontramos la cita que se ha hecho famosa:

En América tenemos hoy, además de nuestro renombre incontrovertible, tú la fama de ser más ebrio que Anakreón; Díaz Mirón, la de ser más asesino que Hérkules; y yo la de ser más ladrón que Mercurio. ¡Pobre América que no cuenta sino con nosotros!...

44 Ghiraldo, 1943: 234-235; Archivo del Escritor. 
Esta cita merecería todo un artículo aparte. Digamos solamente que Chocano establece una jerarquía rigurosa, al compararse él mismo con un dios, a Díaz Mirón con un héroe y semidiós, ${ }^{45}$ y a Rubén Darío con un poeta hedonista, refinado y decadente. En los ojos del público, vulgar, mal pensado, calumnioso, el dios se convierte en ladrón, el héroe y semidiós en asesino, y el poeta en un simple borracho.

El 1. ${ }^{\circ}$ de diciembre de 1910 le escribe de Guatemala:

Leí, o creo haber leído, que habías publicado un nuevo volumen de Poemas. No lo conozco. ¿Te habrás olvidado de mí? Ya me verás muy pronto, en situación como no te imaginas... Y volveré a España: jya lo creo! Mi abuelo materno fue vasco: insistir. ${ }^{46}$

El 30 de septiembre de 1911, también de Guatemala:

Mi querido Rubén:

¡Al fin letras tuyas! Bienvenido seas a la casa de mi abierto y sano corazón... Pensé que me creías "muerto". Creeme, Rubén, todo lo contrario: así Anteo. ${ }^{47}$

El 18 de diciembre de 1911, desde Nueva York:

Dentro de pocos días volveré a Guatemala. Dentro de pocos meses estaré en París. Dentro de pocos años me reiré en Madrid. ¡Escríbeme! ${ }^{48}$

"Resalta" - dice su biógrafo- "la obsesión de volver a España e imponerse. Eso hace pensar que el cargo contra el poeta no fue del todo justo; que él fue más bien víctima de su imprudencia o de su arrogancia y

45 Chocano ya comparó a Díaz Mirón con Hércules en un artículo de juventud, publicado en un periódico de Tacna en 1892 (“Salvador Díaz Mirón”, Chocano, 1954: 936-937).

46 Ghiraldo, 1943: 236; Archivo del Escritor.

47 Belmás, 1960: 207; SARD, documento n. ${ }^{\circ} 1462$.

48 Ghiraldo, 1943: 237.

Bol. Acad. peru. leng. 49(49), 2010 
que aquella imputación que le sacó de quicio, repito, varió sustancialmente el curso de su vida" (Sánchez, 1960: 172).

En todo caso, es una pena que no conozcamos el otro lado de la correspondencia: de las cartas de Chocano a Darío, se han conservado trece (si incluimos dos tarjetas y la carta a Francisca Sánchez); de las de Darío a Chocano, que sepamos, ninguna. Y después del célebre preludio a Alma América escrito en 1906, Darío no publicó nada más sobre su amigo: su retrato no aparece ni en Cabezas, ni en Letras, ni en ninguna parte. No lo invitó, como a tantos otros, a colaborar en el Mundial Magazine. No lo menciona en su autobiografía. En la correspondencia de Darío, solo hemos localizado dos referencias al amigo. La primera se encuentra en una carta oficial escrita al presidente Zelaya, el 15 de septiembre de 1908. La referencia es corta, pero hay que citar toda la primera parte, donde Darío, a su vez, cita una carta del doctor Hermann Prowe sobre la situación en Guatemala:

Mi distinguido General y amigo:

Confirmo á Vd mi carta de ayer. Hoy recibo una del Dr. Prowe participandome que Ricardo Trigueros ha sido puesto en libertad. Para que conozca los curiosos detalles que en ella me comunica, le trascribo algunos párrafos.

"Con gusto le aviso que Ricardo Trigueros salió hace 8 días de la cárcel y del país. El milagro lo hizo aparentemente una súplica de algunos miembros del Congreso Médico Panamericano (Costa Rica, Chile, México, Uruguay). Los norteamericanos y salvadoreños se negaron. En verdad fue orden de Washington adonde ahora en tiempo de elecciones temen se descubra la política cochina de Root. Es una pequeña concesión de momento. En realidad sigue Root con Cabrera, Figuero y Gonzales Viquez-Anderson minando a Zelaya, un segundo Castro atacándole adonde es atacable, en Honduras. Allí seguirán las revoluciones.

La "Corte" de Costa Rica quedó burlada porque Cabrera retiró á su delegado Bocanegra y no se apresuró de nombrar otro.

Cabrera hizo un movimiento muy tonto hacia Porfirio como para volverse amigo. Esto lo hace para demostrar a Root que puede 
arreglarse con México, pero aquí encontrarán un carámbano de hielo.

Vendidos a Cabrera están: Gómez Carrillo, Antonio de Arcos en París y por medio de él el Imparcial".

A mi juicio lo del Imparcial no es cierto, pero Meany y Meany se ha quedado con un periódico que fundó Chocano y que sirve de incensario a Estrada Cabrera. A propósito de Chocano, ha sido aquí muy penoso para sus amigos el ruidoso proceso por estafa que le ha entablado el Banco de España. Él pudo irse para Cuba cuando estaba decretado el auto de prisión.

Ghiraldo (1943: 195-196) cita esta carta, pero suprime el párrafo donde Darío se refiere a Chocano. Belmás cita el párrafo escamoteado por Ghiraldo, y, para evitar la impresión de que el poeta está denunciando a su amigo, agrega: "Digamos en descargo de Darío que la información al general Santos Zelaya sobre el caso Chocano era obligada desde el punto de vista diplomático por haber tenido antaño relación el limeño con Zelaya y estar ahora al servicio de Estrada Cabrera, enemigo del régimen imperante en Nicaragua" (1960: 210).

La segunda referencia, más íntima, se encuentra en una carta a Fabio Fiallo (en Nueva York), escrita en Madrid el 6 de noviembre de 1908:

Ya sabrás la desgracia de Chocano. Aunque por lo que veo en ciertos versos suyos, es lo que llaman los franceses crâne. Valiente. ¡Ay de mí, que tiemblo ante las menores cosas de la vida! ${ }^{49}$

Por fin, está el poema, "tu soneto A un poeta que sin duda es para mí", como dice Chocano en su carta del 11-XII-1908. Reza:

Te recomiendo a ti, mi poeta y amigo, que comprendas mañana mi profundo cariño, y que escuches mi voz en la voz de mi niño, y que aceptes la hostia en la virtud del trigo.

49 Darío, 2000: 286. 
Sabe que, cuando muera, yo te escucho y te sigo; que si haces bien, te aplaudo; que si haces mal, te riño; si soy lira, te canto; si cíngulo, te ciño; si en tu cerebro, seso, y si en tu vientre, ombligo.

Y comprende que en el don de la pura vida, que no se puede dar manca ni dividida para los que creemos que hay algo supremo, yo me pongo a esperar a la esperanza ida, y conduzco entre tanto la barca de la vida; Caronte es el piloto, mas yo dirijo el remo. ${ }^{50}$

Según Sánchez se trata de un "retórico soneto: dice menos y más de lo que a cada línea se propone, y lo dice ora bien, ora mal" (1960: 169). Pensamos que el poema expresa sentimientos complejos que su autor, en este momento, no podía expresar de otra manera. En el verso 5: "Sabe que, cuando muera, yo te escucho y te sigo", Sánchez propone una enmienda: "cuando mueras". Pensamos que "cuando muera" es la forma más correcta: el poeta habla de su propia muerte, no de la del amigo. Si se quiere enmendar algo y reducir ambivalencias, se podría, en este mismo verso, correr la coma: "Sabe que, cuando muera yo, te escucho y te sigo”. El yo lírico manifiesta que, por su "profundo cariño”, acompañará, después de su muerte, al poeta y amigo, sea para aplaudirle o para reñirle: se convertirá en su espíritu rector. Después de la muerte de Darío, ¿supo Chocano escuchar la voz de su amigo, en los momentos trágicos que le reservaba el destino, en Guatemala en junio de 1920, en Lima en octubre de 1925, en Santiago en diciembre de 1934? Esto ya es otra cuestión.

\section{Los poetas no coinciden en México...}

Después de su salida de España, Chocano visita Cuba y Santo Domingo, y a partir de fines de 1908 radica en Guatemala, donde reanuda

50 Darío, 1952: 1162 
su amistad con el presidente Estrada Cabrera y conoce a una joven de excelente familia, Margarita Batres Arzu, que será su segunda esposa. Ya citamos dos cartas que desde Guatemala dirige a Darío. En la primera, escrita el $10^{\circ}$ de diciembre de 1910, encontramos la siguiente alusión a la aventura mexicana de Darío:

Entiendo que la situación política de tu país, no te es propicia. Cree que lo siento por ella: no sé cuándo en nuestra América se convenzerán de que tú, yo, y algún otro, estamos por encima de toda política... Seguí tu viaje a México: hubiera deseado estar contigo para infundirte mi energía en tus momentos de desmayo.

¿A qué se refiere exactamente Chocano cuando habla de los "momentos de desmayo" de su amigo? La respuesta está en la autobiografía de Darío, donde nuestro poeta cuenta que el doctor Madriz, sucesor de Zelaya como presidente de Nicaragua, lo nombró para representar a Nicaragua en las fiestas del Centenario de la Independencia que se celebrarían el 15 y 16 de septiembre de 1910 en México; que salió de París y se embarcó inmediatamente, pero en el puerto de La Coruña recibió la noticia del derrocamiento de Madriz por una "revolución" (mejor dicho, contrarrevolución) urdida por los Estados Unidos; que desde La Habana mandó un cablegrama pidiendo instrucciones al nuevo gobierno de su patria, sin recibir respuesta alguna; que al llegar al puerto mexicano de Veracruz fue recibido con entusiasmo por el pueblo, pero con ambivalencia por los representantes oficiales, declarándolo huésped de honor de la nación, pero señalándole a la vez la inoportunidad de su presencia en la capital. Sin quererlo, Darío se convirtió en aquellos días en un símbolo de la lucha antiimperialista:

Entretanto, una gran muchedumbre de veracruzanos, en la bahía, en barcos empavesados y por las calles de la población, daban vivas a Rubén Darío y a Nicaragua, y mueras a los Estados Unidos. ${ }^{51}$

Y llegamos al episodio al cual alude, sin duda, Chocano en su carta:

51 Darío, 1910: 275.

Bol. Acad. peru. leng. 49(49), 2010 
El enviado del Ministerio de Instrucción Pública llegó, con una carta del ministro, mi buen amigo, don Justo Sierra, en que en nombre del presidente de la República y de mis amigos del gabinete, me rogaban que pospusiese mi viaje a la capital. ${ }^{52}$

Todo era saber cómo interpretar la sugerencia de "posponer mi viaje". ¿Fue "posponer" un eufemismo para decir "anular"? O si se trataba realmente de posponer, ¿por cuánto tiempo? ¿Unos días? ¿Unos meses? El relato sigue:

Y me ocurría algo bizantino. El gobernador civil me decía que podía permanecer en territorio mexicano unos cuantos días, esperando que partiese la delegación de los Estados Unidos para su país, y que entonces yo podría ir a la capital; y el gobernador militar, a quien yo tenía mis razones para creer más, me daba a entender que aprobaba la idea mía de retornar en el mismo vapor para La Habana... Hice esto último. ${ }^{53}$

Fue, sin duda, la decisión que tomó Darío de regresar a La Habana, y después a París, la que interpreta Chocano como un "momento de desmayo". Considera Chocano, sin duda, que lo más correcto hubiera sido esperar unos días y después continuar el viaje hacia la capital. En la ciudad de México, muy probablemente, Darío hubiera encontrado personalmente a un viejo ídolo suyo (y de Chocano), el poeta Salvador Díaz Mirón, a quien había celebrado en un soneto publicado en la segunda edición de Azul... y que era a la sazón diputado en el Congreso Federal, donde, después de una vida llena de peripecias, se mantenía, "legislatura tras legislatura, hasta 1910, en una prudente inactividad. Una parte del año la pasaba en México y el resto en Jalapa y en Veracruz" (Castro Leal, 1970: 33). Darío hubiera podido verlo "en el Hotel Iturbide, en donde lo visitaban amigos y admiradores. Gustaba, más que de la conversación, del soliloquio, y, como el viejo marinero de la balada de Coleridge, detenía con la mirada a su interlocutor mientras, durante horas, desarrollaba temas literarios y científicos, y recitaba versos en tres o cuatro idiomas"

\begin{tabular}{ll}
\hline 52 & Ibíd. \\
53 & Ibid.
\end{tabular}


(ibíd.). En las fiestas del centenario, en la ceremonia de la inauguración de la columna de la Independencia sobre el Paseo de la Reforma, Miguel S. Macedo pronunció el discurso oficial, y Díaz Mirón recitó su poema Al Buen Cura, "poesía fina y elaborada que el público no supo apreciar" (ibíd.: 36-37) y que no calzaba con el entusiasmo del pueblo. ${ }^{54}$

Entusiasmo desbordante, porque también, según cuenta Darío, "en la capital, al saber que no se me dejaba llegar a la gran ciudad, los estudiantes en masa, e hirviente suma de pueblo, recorrían las calles en manifestación imponente contra los Estados Unidos. Por la primera vez, después de treinta y tres años de dominio absoluto, se apedreó la casa del viejo cesáreo que había imperado", es decir, del general Porfirio Díaz, que acababa de ser reeligido por séptima vez. "Y allí se vio, se puede decir, el primer relámpago de una revolución que trajera el destronamiento" (Darío, 1910: 276). Efectivamente, Díaz dimitió el 25 de mayo de 1911 y huyó a Europa. En septiembre ya estaba en París (Blumenkron, 1922). Se inició la revolución mexicana, que iba a ofrecer un terreno tan fértil para los sueños, habilidades y ambiciones de Chocano, mientras que Darío, en una carta escrita a Julio Piquet en 1914, se refiere con pesar, quizás con horror, a "México devastado por fraternales rencores" (Darío, 2000: 382).

En 1911, Chocano se dirige a México, encargado por Estrada Cabrera de una misión confidencial cerca de Francisco Madero, quien

54 De hecho, Darío, figura simbólica de la liberación de la poesía, no fue el único excluido de las fiestas del Centenario de 1910. Los porfiristas excluyeron también una buena parte del mismo pasado histórico. Lempérière, al analizar el desfile histórico del 15 de septiembre, llega a la conclusión de que "se trataba de representar crudamente, en sus faustos y libramientos, inmutable a pesar de los cambios de la época, al poder en torno de una figura de jefe: el poder militar vencedor o a punto de serlo de Iturbide y de Cortés; el poder civil sanctificado del emperador indígena y del rey de España encarnado por el virrey. Esta concepción no dejaba espacio ni para los primeros insurgentes, Hidalgo y Morelos -que no ejercieran el poder, ni realmente hubieran vencido en el campo de batalla-, ni para representaciones de la 'libertad', la 'República' o la 'nación'.... Al excluir de los más grandes honores conmemorativos a una parte de los autores de la independencia nacional, vencidos provisionales de la historia, los porfiristas privilegiaron la celebración de una tradición nacional del poder que no tiene nada de republicano ni de universal" (1995: 332, 333).

Bol. Acad. peru. leng. 49(49), 2010 
asciende al gobierno mexicano el 6 de noviembre. En mayo de 1912, se casa en Nueva York; en agosto, llega a México con su esposa guatemalteca, a pasar una luna de miel llena de recitales, fiestas y homenajes, y se conquista su lugar en el ambiente intelectual mexicano. Visita a Madero. El asesinato de Madero y Pino Suárez y la traición de Huerta (febrero de 1913) lo impresionan profundamente. Se atrae la enemistad de Huerta, quien lo expulsa de México en junio de 1913. El 28 de julio, el New York Times, basándose en un discurso de Chocano, revela que el embajador estadounidense Henry Lane Wilson fue cómplice en la conspiración de Huerta y en el asesinato de Madero; el presidente Woodrow Wilson decide no reconocer el gobierno provisional de Huerta y en febrero de 1914 abre la frontera al libre comercio de armas, con lo cual se fortalece el movimiento revolucionario. Este mismo año Chocano retorna a México, en plan de colaborador de Venustiano Carranza y de Pancho Villa. Se convierte en propagandista de la Revolución. Llega a Puerto Rico, portador de una promesa de Carranza: ayudar a la isla para libertarse de los norteamericanos. De Puerto Rico escribe a su madre:

No pueden imaginarse el papel gigantesco que estoy representando, entendiéndome por correo con Carranza, el Presidente Wilson (que es mi gran amigo personal) y con los gobiernos de Cuba, Santo Domingo y Centroamérica. Pronto el Estado de Veracruz estará en poder de la Revolución, ello será el fin de las cosas; y se deberá todo a mí. ${ }^{55}$

Y si el $1 .^{\circ}$ de diciembre de 1910 escribió a Darío: "Ya me verás muy pronto, en situación como no te imaginas...", ahora escribe a su amigo Luis Llorens Torres:

Detrás de cada palabra que yo diga, apuntará una bayoneta para sostenerla... Voy a ser el Verbo. ¡Carranza será la acción! ¡Al fin! He sido más feliz que (¿Diógenes?): ¡ya encontré a nuestro Hombre! ${ }^{56}$

\footnotetext{
55 Sánchez, 1960: 302.

56 Chocano, 1954: 1027-1028; Sánchez, 1960: 303; Romero de Valle, 1963: 242.
} 
"Se demuestra así, dice Sánchez (1960: 325) "que Chocano estuvo al servicio de Carranza; que acudió con su consejo a Villa; que éste sabía que Carranza pagaba la propaganda que Chocano hacía en el exterior en pro de la Revolución Mexicana; que Chocano trató de mantener unidos a ambos jefes, sin intrigar entre ellos; que pretendía saber de economía y finanzas". Al sobrevenir, en 1915, la escisión revolucionaria, Chocano sigue el rumbo de Villa. "Hablar de provechos deducidos de ello", recuerda, "es no haber conocido a quien -si no hubiera sido por míhubiera fusilado a su propio Tesorero, el señor don Sebastián Vargas, por simples e infundadas sospechas de sumas insignificantes de dinero". Villa, entre otras cosas, le confía 60.000 dólares para comprar municiones ("El libro de mi proceso", Chocano, 1954: 1135). En marzo de este año, publica su folleto El programa de la Revolución Mexicana, con prólogo de Villa (Chocano, 1954: 1030-1042). José Vasconcelos recuerda haberlo escuchado declamar sus poemas: "Cuando yo lo oía en el campamento villista recitar sus versos y notábamos el efecto que producía en las chusmas, Chocano me parecía algo así como Homero" (cit. en Romero de Valle, 1963: 242). Para el poeta, "el fracaso personal de España está ya lejos. Lejos, olvidado, vencido, superado. Un nuevo mundo asoma por el horizonte. ¿Por qué no ser él su profeta?" (Sánchez, 1960: 327). El 4 de noviembre de 1914, el diario El Nuevo Tiempo de Tegucigalpa trae la noticia de que "el gran poeta Chocano está loco", "refiriendo una historia truculenta según la cual habían intervenido algunos soldados para contener la furia del poeta demente" (Romero de Valle, 1963: 243). Este mismo mes, Darío, en Barcelona, redacta una crónica donde describe, entre varios ex presidentes americanos exiliados en Europa, a Porfirio Díaz y a Victoriano Huerta. A este último lo llega a conocer personalmente, en la Maison Dorée, el café más elegante de la capital catalana, donde Huerta "va ... a tomar sus coñacs cotidianos" (Darío, 1977: 302).

\section{... pero sí coinciden en Guatemala}

Se sabe que Darío sale de París en mayo de 1914 y se instala en Barcelona con su compañera Francisca Sánchez, su hijo Rubén Darío Sánchez ("Güicho") y su cuñada María; allí recibe la visita de su hijo 
mayor, Rubén Darío Contreras, y de los primos de éste. Las revistas Mundial y Elegancias, dirigidas por Darío y financiadas por los hermanos Guido, dejan de publicarse cuando, en agosto de aquel año, la crisis entre Austria y Serbia se convierte en una gran guerra que involucra casi todas las potencias europeas. Inspirado por un amigo y compatriota, Alejandro Bermúdez, Darío decide hacer una gira por América, para propagar la paz y a la vez recoger dinero. Se embarca el 25 de octubre, con Bermúdez, dejando atrás a su familia. El 12 de noviembre llegan a Nueva York, donde el 8 de enero el poeta recibe la medalla de Artes y Literatura de la Hispanic Society of America, el 20 del mismo mes es elegido miembro de dicha Sociedad, y el 4 de febrero, en la Universidad de Columbia, da una conferencia y lee la oda "Pax" (Darío, 1952: 12171224). Francisco J. Peynado, el director de la revista Las Novedades, y Archer M. Huntington, el fundador de la Hispanic Society of America, le ofrecen banquetes. También "la Liga de Autores ... dio a Darío una gran recepción en la casa de la aristocrática Mrs. Woodruff (en el mundo de las letras Helen S. Woodruff). Había ... unas trescientas personas, gente de letras en su mayoría. ... Creo que se leyó alguna cosa de Darío traducida al inglés" (carta de Pedro Henríquez Ureña a Alfonso Reyes, cit. en Mejía Sánchez, 1970: 55). Este mismo mes el frío espantable de Nueva York le provoca una pulmonía doble; ingresa en el hospital francés; desde la cama del hospital dicta sus impresiones a su hijo mayor que ha llegado a verlo: "La soledad parece que se duplicase. El aislamiento, la casi destrucción de la personalidad, el sentirse solitario, abandonado, olvidado, ponen en el alma una inexpresable opresión de angustia y de desesperanza, sobre todo, en un pueblo de seres distintos, de idioma distinto, de espíritu y mentalidad distintos”. Meses después, el 22 de agosto, esta carta aparecerá en La Nación con el título "Apuntaciones de un hospital" (Darío, 1977: 305-309). 57 "Débil, esquelético, y sin dinero" se traslada a una pensión en la 14 West Street (Torres, 1980: 857). Bermúdez, declarando que ya no lo aguanta, lo abandona "con sus males,

$57 \quad$ Fue la última crónica de Darío que La Nación publicó en vida de éste. Ignoramos por qué tardó seis meses en publicarse. ¿Será que llegó con mucho atraso a Buenos Aires? Tampoco se explica bien la fecha de redacción absurda que alguien le puso: "Nueva York, julio de 1915". En el texto el poeta cuenta cómo a través de los cristales, durante horas, ve caer la nieve... Y se sabe que, desde fines de abril, estaba en Guatemala. 
pero sin su dinero" (Sánchez, 1960: 339). Dos amigos guatemaltecos, entonces, el diplomático Joaquín Méndez y el poeta Máximo Soto Hall, hacen trámites en su favor, y consiguen una invitación por parte de Manuel Estrada Cabrera, presidente de Guatemala, sangriento dictador y amigo de los poetas. El "Mecenas guatemalteco", como lo llama Enrique Gómez Carrillo (Darío, 2000: 401), estaba "deseoso de pasar a la inmortalidad en versos de Darío" (carta de Pedro Henríquez Ureña, op. cit.: 54). El 8 de abril, cuando la primavera llega a Nueva York, Darío se embarca nuevamente. Su plan es, después de una corta estancia en Guatemala, seguir hacia la Argentina. "El vapor de la Escuadra Blanca de la U. F. C., que ha de conducirme, está ya anclado en su pier de Battery Place. Mis baúles sobre sus tatuajes viejos tienen parches nuevos. Vuelvo a la república Argentina pasando por el trópico", explica, y pone como título a la crónica que redacta a bordo: "De New York a Buenos Aires por el Pacífico" (tal vez, por distracción, escribiendo "Pacífico" en vez de "trópico"). "La crónica", comenta Arellano, "escrita sobre el Atlántico, quedó inconclusa. Darío la trajo consigo a Nicaragua y su viuda Rosario Murillo la envió al diario bonaerense, donde se publicó por primera vez el 28 de abril de 1940" (Darío, 1983). El 20 de abril Darío llega a Puerto Barrios y se traslada a la capital guatemalteca, donde es hospedado en el Hotel Imperial (Chocano prefería el Gran Hotel). Muy contra su voluntad, permanece en Guatemala desde abril hasta octubre, "al principio muy agasajado por Estrada Cabrera" (Sánchez, 1960: 338), quien está preparando su tercera reelección y a quien alaba en poemas, artículos y entrevistas. Es visitado por innúmeros amigos y admiradores, y también, nuevamente, por su primer hijo, Rubén Darío Contreras, quien, en esta ocasión, se revela como un eminente pianista. Darío quiere continuar su viaje y trasladarse a la Argentina; sueña con recuperar su salud en las soledades de Neuquén, en Patagonia, donde tiene un amigo (Darío, 2000: 381), pero "desgraciadamente no le llegan los recursos para movilizarse, y Cabrera pagará las cuentas del hotel, pero de ninguna manera el pasaje a Buenos Aires" (Torres, 1980: 865). Y ¿por qué no le llegan sus habituales recursos, es decir, las remesas de $\mathrm{La}$ Nación? ¿Ya no escribe crónicas? En "Apuntaciones de hospital", había anunciado una crónica sobre "el desarrollo mental de la mujer en los Estados Unidos", donde seguramente hubiera mencionado a Helen S. 
Woodruff, a Alice Stone Blackwell, a Isabel F. Hapgood y a Agnes Blake Poor, la primera, difusora, y las otras traductoras de sus poemas (Darío, 1977: 308). En "De New York a Buenos Aires por el Pacífico" se refiere a "Mr. Archer M. Huntington, el multimillonario hispanista de la Quinta Avenida, de cuya labor he de hablaros en otra ocasión” (Darío, 1983). En el Hotel Imperial comienza a redactar una crónica titulada "En la tierra del Quetzal”, que queda inconclusa (Torres, 1980: 867). En fin, en todo el año 1915, el diario bonaerense sólo publica cinco crónicas de Darío, todas escritas en Nueva York (Zanetti, 2004: 171). La explicación es que "indudablemente Estrada Cabrera ha dado orden de que no se dé curso a las cartas del poeta a La Nación, y es por eso que han pasado siete meses sin recibir de allá los recursos para irse" (Torres, 1980: 868). Finalmente, como reaparece Bermúdez, con una nueva intriga, y como también reaparece Rosario Murillo, esposa legal de Darío, el poeta se va con ella, a morir en Nicaragua.

En estos seis meses, ¿recibió Darío la visita de Chocano? Indudablemente, aunque ni Watland (1965), ni Torres Bodet (1966), ni Torres (1980) mencionan el hecho. En los últimos meses del año, ya terminada su misión en México, Chocano "estaba reintegrado a su hogar guatemalteco; saboreando la compañía de Rubén” (Sánchez, 1960: 338). Federico Hernández de León, escritor y periodista guatemalteco, ${ }^{58}$ que pasó en la cárcel, por órdenes de Estrada Cabrera, los seis meses de la estancia de Darío en Guatemala, pero aún así se daba cuenta de muchas cosas, lo explica en una carta dirigida a Sánchez y reproducida por éste:

Chocano visitaba a menudo a Darío, encastillado en el cuarto de hotel que le sirviera de residencia por una hipócrita dádiva de Estrada Cabrera. La amistad entre los dos poetas estaba resfriada. ... Las entrevistas entre los dos poetas máximos giraban muchas veces en torno a las aventuras de Chocano en México. Darío

$58 \quad$ Federico Hernández de León (1883-1959) fue el autor, posteriormente, de las siguientes obras: Dos crepúsculos (novela, 1919); El Libro de las entrevistas (1922); El libro de las efemérides (3 vols., 1925-1927); Viajes presidenciales; breves relatos de algunas expediciones administrativas del general don Jorge Ubico (1940); De las gentes que conocí (2 vols., 1958). 
zumbaba sus ironías que Chocano contestaba exaltando a su héroe elegido. - Villa, el flamígero, insistía Chocano, es el tipo de caudillo legendario representativo de una época y de una raza. Hombre de costumbres severas; ¡no fumaba!, odiaba la bebida y a los bebedores. Darío se sonreía y remataba: -Pero es un bandido... ${ }^{59}$

"La causa", sigue el biógrafo de Chocano, "del supuesto resfriamiento de la amistad de ambos poetas la atribuye Hernández de León a unas cartas de Alejandro Sawa a Chocano, en que le refería las malediciencias de Darío respecto al incidente del Banco de España” (340).

Cuando Darío muere, el 7 de febrero de 1916, Chocano deplora su muerte con evidente sentimiento. Chocano, quien, con todo y ser peruano, o quizás por ello mismo, pasó los años más importantes y felices de su vida en Centroamérica, comprendía y apreciaba profundamente la manera como la personalidad y la poesía de Darío estaban arraigadas en su patria nicaragüense. Esto se nota claramente en los dos poemas que dedicó a su memoria, "La última visión" (1916) y "La flauta encantada" (1921). El primero comienza con estos versos:

Por sus ojos, cansados de recoger el brillo feérico de las urbes, pasó un último afán: ver el paisaje, a un tiempo misterioso y sencillo, de sus nativas tierras -bosque, lago y volcán.

\section{Y termina:}

El bosque grave, el lago suave, el volcán fuerte para siempre hoy dormidos en tus ojos están... ¡Viste juntas las caras del Amor y la Muerte: me lo han dicho tu bosque, tu lago y tu volcán! ${ }^{60}$

\footnotetext{
59 Sánchez, 1960: 339-340.

60 Chocano, 1954: 787-788.
} 


\section{BIBLIOGRAFÍA}

ARELLANO, Jorge Eduardo, 2009: "Chocano y su relación con Darío y Nicaragua.” El Nuevo Diario (Managua), 24 de octubre.

BELMÁS, Antonio Oliver, 1960: Este otro Rubén Darío. Barcelona: Aedos.

BELMÁS, Antonio Oliver, 1968: Este otro Rubén Dario. Madrid: Aguilar. 2. ${ }^{\text {a }}$ ed. corregida y aumentada.

BLUMENKRON, Fernando, 1922: Porfirio Díaz en el destierro: impresiones de viaje y entrevistas con el Ex-Presidente de México efectuadas en septiembre de 1911 en París. México: Linotipografía Artística.

CASTRO LEAL, Antonio, 1970: Díaz Mirón. Su vida y su obra. México: Porrúa.

CONDE, Carmen, 1964: Acompañando a Francisca Sánchez. (Resumen de una vida junto a Rubén Darío.) Managua: Cardoza.

CHOCANO, José Santos, 1954: Obras completas. Compiladas, anotadas y prologadas por Luis Alberto Sánchez. México: Aguilar.

DARÍO, Rubén, 1906: Opiniones. Madrid: Fernando Fe.

- 1910: La vida de Rubén Darío escrita por él mismo. Barcelona: Maucci.

1952: Poesías completas. Edición, introducción y notas de Alfonso Méndez Plancarte. Madrid: Aguilar.

- 1977: Escritos dispersos de Rubén Dario (recogidos de periódicos de Buenos Aires). Edición, compilación y notas de Pedro Luis Barcia. La Plata: Universidad Nacional de La Plata, Facultad de Humanidades y Ciencias de la Educación.

. 1983: "De New York a Buenos Aires por el Pacífico. Una crónica desconocida de Rubén Darío." Edición: Jorge Eduardo Arellano. Nuevo Amancer Cultural (Managua), 30 de enero. 
. 2000: Cartas desconocidas de Rubén Dario, 1882-1916. Edición: Jorge Eduardo Arellano. Managua: Academia Nicaragüense de la Lengua.

2005: Cantos de vida y esperanza. Los cisnes y otros poemas. Edición y notas: Pablo Kraudy, Jorge Eduardo Arellano. Managua: Instituto de Cultura.

. 2006: Crónicas desconocidas. Edición crítica, introducción y notas de Günther Schmigalle. Berlin: Tranvía.

DOMÉNECH, Jordi, 2003: "Un poeta olvidado, Nilo Fabra, y una poesía desconocida a Valle-Inclán". El Pasajero (http://www.el pasajero. com/nilofabra.html, consultado el 30 de octubre de 2009).

GHIRALDO, Alberto, 1943: El archivo de Rubén Darío. Buenos Aires: Losada.

GONZÁlEZ-BLANCO, Andrés, 1908: "Prólogo. El poeta de América. José Santos Chocano.” En: José Santos Chocano: ¡Fiat Lux! (Poemas varios.) París: Paul Ollendorff. pp. I-XCIII.

LEMPÉRIÈRE, Annick, 1995: "Los dos Centenarios de la Independencia Mexicana (1910-1921): de la historia patria y la antropología cultural." Historia Mexicana, 45, n. ${ }^{\circ}$ 2: 317-352.

MEJÍA SÁNCHEZ, Ernesto, 1970: Cuestiones rubendarianas. Madrid: Ediciones de la Revista de Occidente.

NERVO, Amado, 1955-1956: Obras completas. Edición, estudio y notas de Francisco González Guerrero y Alfonso Méndez Plancarte. 2 tomos. Madrid: Aguilar.

PRESTON, Paul, 2006: Las tres Españas del 36. Barcelona: Random House Mondadori, 2. ${ }^{\mathrm{a}}$ ed.

ROMERO DE VALLE, Emilia, 1963: "México en la poesía y la vida de Chocano." Revista Hispánica Moderna, n. ${ }^{\circ}$ 3/4: 234-251. 
SÁNCHEZ, Luis Alberto, 1960: Aladino o Vida y obra de José Santos Chocano. México, D.F.: Libro Mex.

TORRES, Edelberto, 1980: La dramática vida de Rubén Darío. Ed. definitiva, corregida y ampliada. San José (Costa Rica): EDUCA (Rueda del Tiempo).

1982: La dramática vida de Rubén Darío. La Habana: Arte y Literatura.

TORRES BODET, Jaime, 1966: Rubén Darío. Abismo y cima. México, D.F.: Universidad Nacional Autónoma.

TÜNNERMANN BERNHEIM, Carlos, 2009: "La entrañable amistad de Darío y Doña Fidelina Santiago de Castro". Lengua (Managua), n. ${ }^{\circ} 34$. pp. 220-225.

VARGAS VILA, José María, 1972: Rubén Darío. Barcelona: AHR.

VILlACASTÍN, Rosario M., 1987: Catálogo-archivo Rubén Darío. Madrid: Universidad Complutense.

WATLAND, Charles D., 1965: Poet-Errant: A Biography of Rubén Dario. New York: Philosophical Library.

ZANETTI, Susana, 2004: Rubén Darío en La Nación de Buenos Aires, 1892. 1916. Buenos Aires: Editorial Universitaria.

\section{Correspondencia:}

Günther Schmigalle

Correo electrónico: Schmigalle@BLB-Karlsruhe.de 